Department of Clinical Genetics, Erasmus University Rotterdam, The Netherlands A Wagner

E J Meijers-Heijboer $C$ van der Meer D Lindhout

M F Niermeijer

Department of Human and Clinical Genetics, Leiden University Medical Centre, Wassenaarseweg 72, 2333 AL Leiden, The

Netherlands

A Wagner

Y Hendriks

C Tops

E Bik

A H J T Bröcker-Vriends

M H Breuning

A H Zwinderman

$\mathrm{J}$ Wijnen

R Fodde

Department of Pathology, Leiden University Medical

Centre, The

Netherlands

W J F de Leeuw

$\mathrm{H}$ Morreau

C J Cornelisse

Department of Medical Genetics, University Hospital Groningen, The Netherlands

R Hofstra

Department of Medical Genetics, University Medical Centre Utrecht, The

Netherlands

D Lindhout

The Netherlands Foundation for the Detection of

Hereditary Tumours, The Netherlands H F A Vasen

Department of Pathology, Reinier de Graaf Gasthuis/SSDZ, Delft, The Netherlands

$\mathrm{C}$ van Krimpen

Correspondence to: Dr Fodde,

R.Fodde@LUMC.nl

Revised version received 25 January 2001

Accepted for publication 15 February 2001

\title{
Atypical HNPCC owing to MSH6 germline mutations: analysis of a large Dutch pedigree
}

A Wagner, Y Hendriks, E J Meijers-Heijboer, W J F de Leeuw, H Morreau, R Hofstra, C Tops, E Bik, A H J T Bröcker-Vriends, C van der Meer, D Lindhout, H F A Vasen, M H Breuning, C J Cornelisse, C van Krimpen, M F Niermeijer, A H Zwinderman, J Wijnen, R Fodde

Abstract

Hereditary non-polyposis colorectal cancer (HNPCC) is the most common genetic susceptibility syndrome for colorectal cancer. HNPCC is most frequently caused by germline mutations in the DNA mismatch repair (MMR) genes $M S H 2$ and MLH1. Recently, mutations in another MMR gene, MSH6 (also known as GTBP), have also been shown to result in HNPCC. Preliminary data indicate that the phenotype related to MSH6 mutations may differ from the classical HNPCC caused by defects in $M S H 2$ and $M L H 1$.

Here, we describe an extended Dutch HNPCC family not fulfilling the Amsterdam criteria II and resulting from a MSH6 mutation. Overall, the penetrance of colorectal cancer appears to be significantly decreased $(p<0.001)$ among the MSH6 mutation carriers in this family when compared with $M S H 2$ and $M L H 1$ carriers $(32 \%$ by the age of $80 v>80 \%)$.

Endometrial cancer is a frequent manifestation among female carriers (six out of 13 malignant tumours). Transitional cell carcinoma of the urinary tract is also relatively common in both male and female carriers $(10 \%$ of the carriers).

Moreover, the mean age of onset of both colorectal cancer $(M S H 6 v M S H 2 I M L H 1=$ 55 years $v$ 44/41 years) and endometrial carcinomas (MSH6 $v$ MSH2IMLH1 $=55$ years $v 49 / 48$ years) is delayed. As previously reported, we confirm that the pattern of microsatellite instability, in combination with immunohistochemical analysis, can predict the presence of a MSH6 germline defect.

The detailed characterisation of the clinical phenotype of this kindred contributes to the establishment of genotypephenotype correlations in HNPCC owing to mutations in specific mismatch repair genes.

(F Med Genet 2001;38:318-322)

Keywords: hereditary non-polyposis colorectal cancer; MSH6
Hereditary non-polyposis colorectal cancer (HNPCC) is one of the most common autosomal dominant conditions predisposing to cancer. HNPCC carriers are at risk for the development of a broad spectrum of malignancies including tumours of the colon, endometrium, stomach, small intestine, hepatobiliary system, ureter, renal pelvis, and ovary. ${ }^{1}$ HNPCC is caused by germline mutations in DNA mismatch repair (MMR) genes, predominantly $\mathrm{MSH} 2$ on chromosome $2 \mathrm{p} 16^{2}$ and $M L H 1$ on chromosome $3 \mathrm{p} 21 .^{3}$ In a minority of cases, mutations have been described in other MMR genes like PMS1 and PMS2. ${ }^{4}$ Recently, germline mutations in the MSH6 gene on chromosome 2 p 15 were recognised as a frequent cause of atypical HNPCC, that is, not complying with the clinical "Amsterdam criteria". 5-9

The involvement of MMR genes in HNPCC is reflected by the occurrence of instability of simple repetitive DNA sequences (microsatellite instability or MSI) in tumours from HNPCC patients. Accordingly, more than $90 \%$ of the colorectal tumours and at least $75 \%$ of the endometrial tumours from HNPCC patients display MSI. ${ }^{10-12}$ In sporadic colorectal and endometrial cancer, MSI is found in about $15-30 \%$ of tumours. ${ }^{13} 14$

The first reports on MSH6 germline mutations have indicated that the clinical phenotype of the affected families may differ from the "classical" HNPCC caused by $\mathrm{MSH} 2$ and MLH1 mutations. ${ }^{5-9}$ The penetrance of colorectal cancer seemed to be reduced. However, endometrial cancer was likely to represent a more important clinical manifestation among female MSH6 carriers. The reported mean age of onset of colorectal and endometrial cancer appeared to be delayed in families with $\mathrm{MSH} 6$ germline mutations, 50 years and older compared to 44 (MSH2) and 41 (MLH1) years of age $^{15}$ and 53 years and older compared to 49 (MSH2) and 48 (MLH1) years, respectively. ${ }^{7}$ Notably, MSI analysis of tumours from MSH6 mutation carriers suggested a reduced penetrance of the MSI-H phenotype and preferential instability at mononucleotide repeats. ${ }^{7-9} 12$

Here, we report the clinical and molecular characterisation of a large HNPCC kindred 


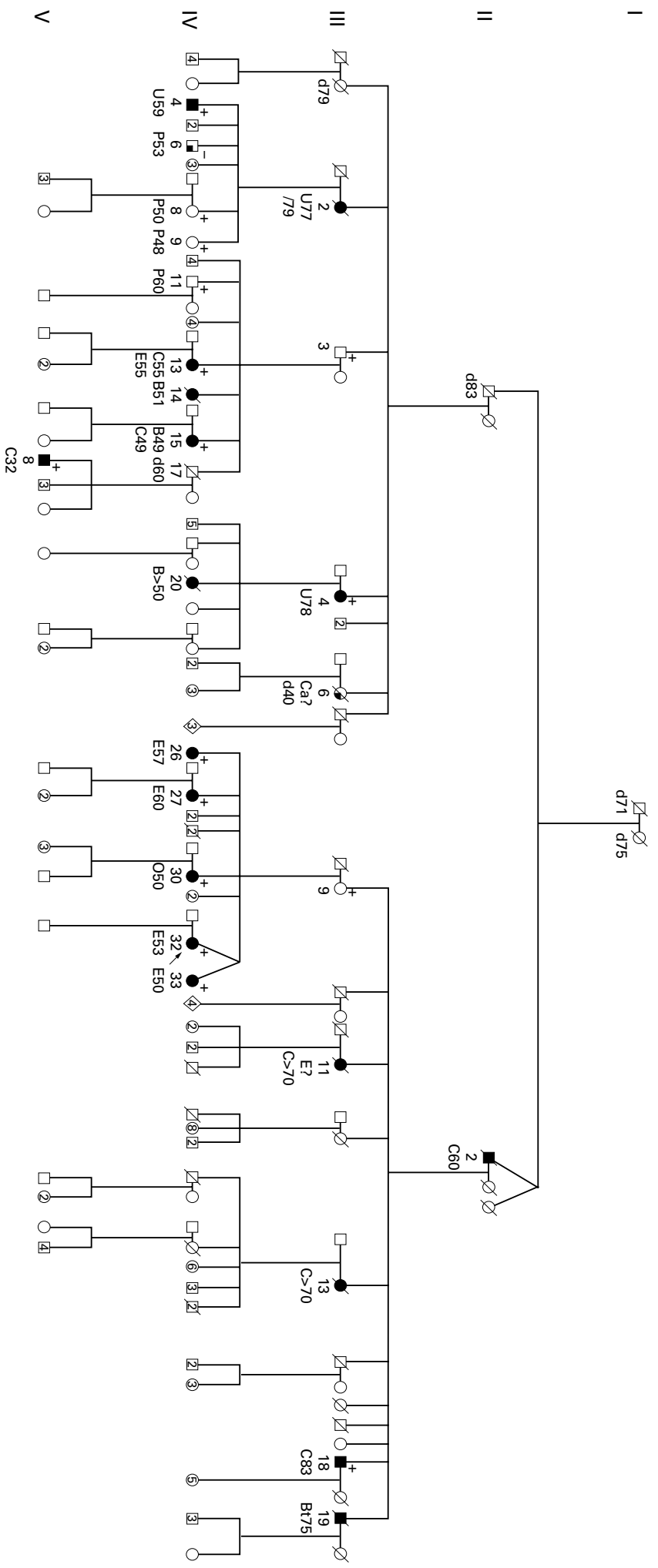

Figure 1 Pedigree of MSH6 family. $C=$ colorectal cancer. $E=$ endometrial cancer. $U=$ urinary tract cancer. $P=$ polyp. $O=$ ovarian cancer. $B=$ breast cancer. $B t=$ brain tumour. Ca? = cancer of unknown origin. $+=$ MSH6 mutation positive. $-=$ MSH6 mutation negative.
Rotterdam by her gynaecologist in 1993. At that time, three of her six sisters were diagnosed with endometrial cancer at 50, 57, and 60 years of age. A fourth sister had developed ovarian cancer (endometroid adenocarcinoma) at the age of 50. The proband's father died at the age of 85 without any symptoms of HNPCC. Her mother underwent a hysterectomy for leiomyomata at 55 and was in good health at 92 years of age.

The differential diagnosis in this family included HNPCC. Mutation analysis of the $M L H 1$ and $M S H 2$ genes by PCR and DGGE in one of the affected sisters of the proband did not show any pathogenic mutation. In the meantime, the proband developed endometrial cancer at the age of 53, the fourth case of endometrial cancer in this sibship.

As soon as MSH6 mutation analysis became available, mutation screening was performed and a frameshift mutation (del T codon 594) in exon 4 was identified. ${ }^{7}$ The proband, her affected sisters, and mother were found to carry the same mutation.

At the request of the proband, family members were informed about the findings and were invited to contact the Department of Clinical Genetics for additional information and/or to be tested for the presence of the mutation.

We were also able to link the family to another kindred under investigation at the Department of Clinical Genetics at the Leiden University Medical Centre.

\section{Mutation analysis}

In total, DNA testing for the MSH6 mutation was performed in 80 out of 132 living relatives with at least a $25 \%$ risk of being carrier of the MSH6 mutation (fig 1), 27 males (out of 63, $43 \%$ ) and 53 females (out of $69,77 \%$ ). Out of these 132 relatives, 11 were previously diagnosed with an HNPCC related tumour and all of them were tested. Two tested unaffected relatives were obligate carriers. Out of 75 carriers at $50 \%$ risk and 44 at $25 \%$ risk, $46(61 \%)$ and $21(48 \%)$ were tested, respectively (tables 1 and 2).

Ten of the 11 affected subjects were carriers of the familial MSH6 mutation. The patient (IV.6) negative for the mutation was a 55 year old male, diagnosed with numerous tubulovillous adenomas at the age of 53. Since his clinical presentation was suggestive of familial adenomatous polyposis (FAP), though with a delayed age of onset, mutation analysis of the $A P C$ gene was performed. This did not show any alteration.

The MSH6 mutation was confirmed in both unaffected obligate carriers.

Out of the 46 tested healthy subjects with a $50 \%$ risk for the mutation, $17(37 \%)$ were found to carry the MSH6 mutation; none of those with a $25 \%$ risk tested positive (table 2 ).

All 17 unaffected mutation carriers above the age of 25 years (five males and 12 females) were offered the generally accepted surveillance for HNPCC, namely colonoscopy every one to two years, yearly gynaecological examination with vaginal ultrasound and CA125 blood testing 
Table 1 (Pre)malignant tumours in the extended Dutch MSH6 family

\begin{tabular}{llcl}
\hline Patient & Tumour & $\begin{array}{c}\text { Age at } \\
\text { diagnosis }\end{array}$ & MSH6 mutation \\
\hline II.2 & Colorectal cancer & 60 & Obligate carrier \\
III.2 & Transitional cell carcinoma right pyelum & 77 & Obligate carrier \\
& \& transitional cell carcinoma left ureter & 79 & \\
III.4 & Transitional cell carcinoma & 78 & + \\
III.6 & Unknown & 40 & Not tested \\
III.11 & Endometrial carcinoma & $?$ & Obligate carrier \\
& Colon carcinoma & 770 & \\
III.13 & Colon carcinoma & 770 & Not tested \\
III.18 & Colon carcinoma & 83 & + \\
III.19 & Astrocytoma & 75 & Not tested \\
IV.4 & Transitional cell carcinoma ureter & 59 & + \\
IV.6 & Multiple adenomatous polyps of the colon & 53 & - \\
IV.8 & Adenoma & 50 & + \\
IV.9 & Adenoma & 48 & + \\
IV.11 & Tubulovillous adenoma & 60 & + \\
IV.13 & Endometrial \& rectal carcinoma & 55 & + \\
IV.14 & Breast cancer & 51 & Not tested \\
IV.15 & Breast \& colon carcinoma & 49 & + \\
IV.20 & Breast cancer & $>50$ & Not tested \\
IV.26 & Endometrial carcinoma & 57 & + \\
IV.27 & Endometrial carcinoma & 60 & + \\
IV.30 & Endometroid adenocarcinoma ovary & 50 & + \\
IV.32 & Endometrial carcinoma & 53 & + \\
IV.33 & Endometrial carcinoma & 50 & + \\
V.8 & Colorectal cancer & 32 & + \\
& & & +
\end{tabular}

+ indicates the presence of the MSH6 mutation.

- indicates the absence of the MSH6 mutation.

Table 2 Results of mutation analysis

\begin{tabular}{lccccccc}
\hline & Male & \multicolumn{5}{c}{ Female } & Total \\
\hline Pretest risk & $100 \%^{\star}$ & $50 \%$ & $25 \%$ & $100 \% \star$ & $50 \%$ & $25 \%$ & \\
Tested & 5 & 15 & 7 & 8 & 31 & 14 & 80 \\
MSH6+ & 4 & 4 & 0 & 8 & 13 & 0 & 29 \\
MSH6- & 1 & 11 & 7 & 0 & 18 & 14 & 51 \\
Not tested & 0 & 19 & 17 & 0 & 10 & 6 & 52 \\
Total & 5 & 34 & 24 & 8 & 41 & 20 & 132
\end{tabular}

${ }^{\star}$ Relatives with an HNPCC related tumour and obligate carriers.

(for female carriers), and yearly urine sediment testing and cytology. During the first screening the following diagnoses were made: a tubulovillous adenoma with dysplasia in the proximal rectum of a 60 year old male; an invasive ductal adenocarcinoma of the breast and an adenocarcinoma of the colon in a 49 year old female; a small tubular adenoma and endometrial hyperplasia in a 50 year old female; and an adenoma in a female aged 48. Of the remaining 13 carriers, four were under the age of 45 and four were above 70 years without any symptoms of the genetic predisposition. However, a 92 year old female underwent a hysterectomy because of leiomyomata of the uterus at the age of 55 .
The family included five dead obligate mutation carriers, three females and two males. Three of them had been diagnosed with a HNPCC related tumour (table 1). One male reached the age of 83 without having developed any HNPCC related tumour.

We were not able to determine the MSH6 status of five cancer patients in this family: one colorectal cancer (onset $>70$ ) in a female patient (III.13) whose 13 descendants tested negative for the mutation; one male with an astrocytoma (III.19) at the age of 75, three of whose four children did not carry the mutation; two breast cancer patients (IV.14, IV.20, onset $>50$ ); and one patient with cancer of unknown origin around the age of 40 (III.6).

In total, 34 mutation carriers (29 alive and five dead) were identified in this pedigree, 17 of whom developed a (pre)malignant tumour (table 1). Of the carriers with a malignancy, four had two primary HNPCC related tumours. Using the Kaplan-Meyer method, 7\% of the carriers developed colorectal cancer by the age of 50 years and $32 \%$ by the age of 80 years (mean age of onset 55 years, ranging from 32 to 83 years). Of the female carriers, $52 \%$ developed endometrial cancer by the age of 80 and all of them were diagnosed above the age of 50 years. Three carriers had a papillary transitional cell carcinoma of the urinary tract $(10 \%$ of the carriers).

\section{Microsatellite instability (MSI) and immunohistochemical (IHC) analyses} We performed MSI analysis and/or immunohistochemistry with antibodies against MLH1, MSH2, and $\mathrm{MSH}^{12}$ on tumour samples derived from 12 subjects; in four cases, two independent tumour samples were tested (table 3).

Using the markers recommended by Boland et $a l,{ }^{16} \mathrm{MSI}$ analysis showed variable patterns (table 3). However, all tumour samples derived from the MSH6 carriers displayed instability of at least one mononucleotide marker when an extended set of markers, including BAT40, was used.

Immunohistochemical (IHC) analysis of the MSH6 protein in tumour sections showed no expression in any of the samples tested, with

Table 3 Microsatellite and immunohistochemical analysis in tumours from 12 affected relatives

\begin{tabular}{|c|c|c|c|c|c|c|c|c|c|c|c|c|c|c|c|c|}
\hline & \multicolumn{16}{|c|}{ Subject } \\
\hline & III. 2 & & III. 4 & III. 13 & III. 18 & IV.4 & & IV.6 & IV.13 & & IV.15 & & IV.26 & IV.27 & IV.30 & IV.32 \\
\hline Tumour type & $\mathrm{U}$ & $\mathrm{U}$ & $\mathrm{U}$ & $\mathrm{C}$ & $\mathrm{C}$ & $\mathrm{U}$ & $\mathrm{U}$ & $\mathrm{P}$ & $\mathrm{R}$ & $\mathrm{E}$ & $\mathrm{C}$ & B & $\mathrm{E}$ & $\mathrm{E}$ & $\mathrm{O}$ & $\mathrm{E}$ \\
\hline Microsatellite status & $\mathrm{H}$ & $\mathrm{H}$ & $\mathrm{L}$ & NT & $\mathrm{H}$ & $\mathrm{H}$ & $\mathrm{L}$ & $\mathrm{s}$ & $\mathrm{H}$ & $\mathrm{L}$ & $\mathrm{s}$ & $\mathrm{H}$ & $\mathrm{H}$ & $\mathrm{L}$ & $\mathrm{H}$ & $\mathrm{s}$ \\
\hline \multicolumn{17}{|l|}{ Mononucleotide markers } \\
\hline BAT25* & + & + & + & NT & + & + & - & - & + & - & - & + & + & - & + & - \\
\hline BAT26* & NT & + & - & NT & + & + & + & - & + & + & - & + & + & + & + & - \\
\hline BAT40 & + & + & + & NT & + & + & $+/-$ & - & + & + & + & + & NT & + & + & + \\
\hline \multicolumn{17}{|l|}{ Dinucleotide markers } \\
\hline $\mathrm{D} 2 \mathrm{~S} 123^{\star}$ & + & NT & - & NT & - & - & NT & - & - & - & - & - & - & - & - & - \\
\hline D5S346* & - & + & - & NT & + & - & - & - & + & - & - & - & - & - & - & - \\
\hline $\mathrm{D} 17 \mathrm{~S} 250^{\star}$ & + & NT & - & NT & + & - & - & - & + & - & - & - & - & - & - & - \\
\hline \multicolumn{17}{|l|}{ Immunohistochemistry } \\
\hline MLH1 & NT & NT & + & ++ & + & + & NT & + & + & ++ & + & + & + & + & ++ & +++ \\
\hline $\mathrm{MSH} 2$ & NT & NT & + & ++ & ++ & + & NT & + & - & + & + & + & ++ & + & + & ++ \\
\hline MSH6 & NT & NT & - & + & - & - & NT & + & - & - & - & - & - & - & NT & - \\
\hline
\end{tabular}

$\star=$ markers recommended by NCI for MSI analysis. ${ }^{16}+=$ Unstable. $-=$ Stable. NT $=$ not tested/not conclusive. $\mathrm{H}=\mathrm{MSI}$ high according to NCI recommendations. ${ }^{16} \mathrm{~L}=$ MSI low according to NCI recommendations. ${ }^{16} \mathrm{~S}=$ MSI stable according to NCI recommendations. ${ }^{16} \mathrm{C}=$ colon tumour. $\mathrm{U}=$ urinary tract tumour. $\mathrm{E}=$ endometrial tumour. $\mathrm{O}=$ ovarian tumour. $\mathrm{R}=$ rectal tumour. $\mathrm{P}=$ polyp. $\mathrm{B}=$ breast tumour.

Immunohistochemistry: $+++=$ strong staining, $++=$ moderate staining, $+=$ weak staining, $-=$ no staining. 
the exception of III.13 and IV.6. Patient III.13 could not be tested for either the presence of the germline mutation or for MSI, and is likely to represent a phenocopy, in view of the late age of onset (colon carcinoma at $>70$ years) and the failure to detect the MSH6 mutation in her 13 descendants. We were able to perform MSI analysis in a single adenoma from patient IV.6 that did not display instability for any of the tested markers. MLH1 and MSH2 IHC analysis was positive in all samples with the exception of the rectal carcinoma from IV.13, negative for $\mathrm{MSH} 2$.

\section{Discussion}

Genetic heterogeneity and variable phenotypic expression represent major complications in the diagnosis and clinical management of HNPCC, one of the most common inherited predispositions to multiorgan tumorigenesis. Although the hallmark of this condition is represented by colorectal lesions, a broad range of cancer types, including tumours of the endometrium, stomach, small intestine, hepatobiliary system, and ureter, are established clinical expressions of HNPCC. The vast majority of HNPCC cases are known to result from germline mutations in the DNA mismatch repair genes $\mathrm{MSH} 2$ and $M L H 1 .{ }^{17}$ In these kindreds, high penetrance and early onset of colorectal and endometrial cancer are the major clinical features. The set of diagnostic criteria, Amsterdam criteria I and II, established by the International Collaborative Group on HNPCC ${ }^{1819}$ well serve the purpose of selecting families with a high likelihood of carrying $\mathrm{MSH} 2$ and $\mathrm{MLH} 1$ mutations. ${ }^{17}$ More recently, atypical HNPCC families, that is, not complying with the Amsterdam criteria (ACI and II) though clearly suggestive of a HNPCClike inherited condition, have been reported to be caused by germline mutations in a third MMR gene, namely MSH6. $^{7-9}$ Preliminary phenotypic analysis of these families showed a reduced occurrence of colorectal cancer and a prevalence of endometrial tumours.

Here, we have presented a detailed analysis of an extended Dutch HNPCC pedigree resulting from an inactivating germline mutation of the MSH6 gene.

The expression of the MSH6 mutation in this family suggests a reduced penetrance and a delayed age of onset for colorectal cancer. Using the Kaplan-Meyer method, 7\% of the carriers developed colorectal cancer by the age of 50 years and $32 \%$ by the age of 80 years. This is significantly reduced $(\mathrm{p}<0.001)$ compared to "classical" HNPCC caused by $\mathrm{MSH} 2$ and $M L H 1$ ( $~ 55 \%$ by age 50 and $>80 \%$ by age 80). ${ }^{15}$ Admittedly, these calculations are based on a limited number of cases and may represent an overestimate because not all healthy eligible relatives were tested for the MSH6 mutation. Moreover, the selection bias introduced when studying a family with such a striking clinical history may also lead to an overestimation of the penetrance. The mean age of onset of the colorectal carcinomas in this family is 55 years. This is delayed when compared with HNPCC families caused by MSH2 (44 years) and MLH1 (41 years) mutations. ${ }^{15}$ This delayed age of onset may also bias the estimated penetrance. Notably, the youngest diagnosed case was at 32 years, implying that periodic screening recommendations should not differ from those established for classical HNPCC until more data are available.

In this family, endometrial cancer is the most common tumour type (six out of 13 malignant tumours) among female carriers. All the endometrial cancers were diagnosed above the age of 50 and their mean age of onset was 55 years, that is, five to 10 years later when compared with "classical" HNPCC caused by mutations in $M L H 1$ and $M S H 2 .^{7}{ }^{20}$

Another striking clinical phenotype in this family is the papillary transitional cell carcinoma of the ureter and renal pelvis observed in three relatives ( $10 \%$ of the carriers). Notably, the lifetime cumulative risk of this tumour type in $M L H 1$ or $M S H 2$ mutation carriers is only $2.6 \% .^{21}$

As previously reported by us and others, ${ }^{7-9}$ the MSI phenotype caused by loss of MSH6 function is reduced when compared with $M L H 1$ and $M S H 2$, and differs in its predominance at mononucleotide runs. This is in agreement with previous studies on yeast and mouse model systems. ${ }^{22}{ }^{23}$ From this point of view, the set of markers previously recommended by NCI for MSI analysis ${ }^{16}$ may not be suitable for MSH6 mutation carriers and should be complemented with a set of mononucleotide markers. In six of the cases reported here (III.4, IV.4U, IV.13E, IV.15C, IV.27, and IV.32) (table 3), instability was observed at only one or two mononucleotide repeats (one of which was not included in the NCI panel) leading to an MSI-low or stable classification. In five of these cases, IHC was performed and indicated the loss of MSH6 in the tumour. Therefore, we recommend IHC analysis in MSI-L and MSS tumours from cases with a family history suggestive of HNPCC. ${ }^{12}$

We also show the feasibility of the IHC approach not only on colorectal tumours but also in carcinoma of the endometrium, urinary tract, and breast. The latter finding is relevant for the inclusion of breast cancer in the HNPCC tumour spectrum: breast tumour samples from IV.15 showed both MSI-high and a negative IHC staining pattern in accordance with the presence of the MSH6 germline mutation in this person. Two additional perimenopausal breast cancer cases were found in the present study (IV.14 and IV.20). However, as no material was available from these patients, we could not establish their MSH6 mutation carrier status.

IHC analysis was also helpful in the assessment of the likely phenocopy status relative to III.13. As a limited amount of a colorectal carcinoma was available from this dead patient, we limited our analysis to IHC and found normal MSH6 protein expression. Moreover, all her descendants tested negative for the mutation. Another dead patient from 
this family, III.19, was diagnosed with astrocytoma at the age of 75 . Again, no archival material was available from this patient. However, the delayed age of onset and the fact that three of his children tested negative for the mutation, do not allow us to draw any conclusion on the relationship between the presence of the brain tumour and the MSH6 defect.

Patient IV.6 presented with a clinical phenotype more suggestive of attenuated polyposis ${ }^{24}$ rather than HNPCC. Accordingly, MSI analysis of the colonic polyps was negative (MSS) and normal MSH6 expression was found by IHC. Failure to detect the MSH6 mutation in this patient confirmed that the attenuated polyposis is likely to result from an unlinked genetic predisposition.

In conclusion, the clinical features associated with MSH6 germline mutations strongly support the inclusion of endometrial cancer and transitional cell cancer of the ureter and renal pelvis in the diagnostic criteria for HNPCC in the new Amsterdam Criteria (ACII) as formulated by the ICG-HNPCC. ${ }^{19}$ In addition, we propose to perform MSI in combination with IHC in all Amsterdam negative families with a clustering of endometrial or urinary tract cancers. The combined MSI and IHC analysis will direct subsequent mutation analysis for MSH6.

We thank Dr J J P M Pieters, gynaecologist, for referring the family to the Department of Clinical Genetics, Rotterdam.

1 Lynch HT, de la Chapelle A. Genetic susceptibility to nonpolyposis colorectal cancer. F Med Genet 1999;36:801-18. Garber J, Kane M, Kolodner R. The human mutator gene homolog MSH2 and its association with hereditary nonpolyposis colon cancer. Cell 1993:75:1027-38.

3 Bronner CE, Baker SM, Morrison PT, Warren G, Smith LG, Lescoe MK, Kane M, Earabino C, Lipford J, Lindblom A, Tannergård P, Bollag RJ, Godwin AR, Ward DC, Nordenskiøld M, Fishel R, Kolodner R, Liskay RM. DC, Nordenskjøld M, Fishel R, Kolodner R, Liskay RM. Mutation in the DNA mismatch repair gene homologue
hMLH1 is associated with hereditary non-polyposis colon hMLH1 is associated with hered

4 Nicolaides NC, Papadopoulos N, Liu B, Wei YF, Carter KC, Ruben SM, Rosen CA, Haseltine WA, Fleischmann RD, Fraser CM, Adams MD, Venter JC, Malcolm GD, Hamilton SR, Petersen GM, Chapelle de la A, Vogelstein B, Kinzler KW. Mutations of two PMS homologues in hereditary nonpolyposis colon cancer. Nature 1994;371:7580 .

5 Akiyama Y, Sato H, Yamada T, Nagasaki H, Tsuchiya A, Abe R, Yuasa Y. Germ-line mutation of the hMSH6/GTBP gene in an atypical hereditary nonpolyposis colorectal cancer kindred Cancer Res 1997:57:3920-3.

6 Miyaki M, Konishi M, Tanaka K, Kikuchi-Yanoshita R, Muraoka M, Yasuno M, Igari T, Koike M, Chiba M, Mori T. Germline mutation of MSH6 as the cause of hereditary nonpolyposis colorectal cancer. Nat Genet 1997;17:271-2.

7 Wijnen J, de Leeuw W, Vasen H, van der Klift H, Moller P, Stormorken A, Meijers-Heijboer H, Lindhout D, Menko F, Vossen S, Moslein G, Tops C, Brocker-Vriends A, Wu Y, Hofstra R, Sijmons R, Cornelisse C, Morreau H, Fodde R. Fomilial endometrial cancer in female carriers of MSH6 Familial endometrial cancer in female carrier
germline mutations. Nat Genet 1999;23:142-4.

germline mutations. Nat Genet 1999;23:142-4.
8 Wu Y, Berends MJ, Mensink RG, Kempinga C, Sijmons $\mathrm{RH}$, van Der Zee AG, Hollema H, Kleibeuker JH, Buys $\mathrm{CH}$, Hofstra RM. Association of hereditary nonpolyposis colorectal cancer-related tumors displaying low microsatelite instability with MSH6 germline mutations. Am f Hum Genet 1999;65:1291-8.

9 Kolodner RD, Tytell JD, Schmeits JL, Kane MF, Gupta RD, Weger J, Wahlberg S, Fox EA, Peel D, Ziogas A, Garber JE, Syngal S, Anton-Culver H, Li FP. Germ-line msh6 mutations in colorectal cancer families. Cancer Res 1999;59:5068-74.

10 Fujiwara T, Stolker JM, Watanabe T, Rashid A, Longo P, Eshleman JR, Booker S, Lynch HT, Jass JR, Green JS, Kim $\mathrm{H}$, Jen J, Vogelstein B, Hamilton SR. Accumulated clonal genetic alterations in familial and sporadic colorectal carcigenetic alterations in familial and sporadic colorectal carciquences. Am f Pathol 1998;153:1063-78.

11 Ichikawa Y, Lemon SJ, Wang S, Franklin B, Watson P, Knezetic JA, Bewtra C, Lynch HT. Microsatellite instability and expression of MLH1 and MSH2 in normal and malignant endometrial and ovarian epithelium in hereditary nonpolyposis colorectal cancer family members. Cancer Genet Cytogenet 1999;112:2-8

12 de Leeuw WJ, Dierssen J, Vasen HF, Wijnen JT, Kenter GG, Meijers-Heijboer H, Brocker-Vriends A, Stormorken A, Moller P, Menko F, Cornelisse CJ, Morreau H. Prediction of a mismatch repair gene defect by microsatellite instability and immunohistochemical analysis in endometrial tumours from HNPCC patients. F Pathol 2000;192:32835 .

13 Ionov Y, Peinado MA, Malkhosyan S, Shibata D, Perucho $M$. Ubiquitous somatic mutations in simple repeated sequences reveal a new mechanism for colonic carcinogenesis. Nature 1993;363:558-61.

14 Helland A, Borresen-Dale AL, Peltomaki P, Hektoen M, Kristensen GB, Nesland JM, de la Chapelle A, Lothe RA. Microsatellite instability in cervical and endometrial carcinomas. Int 7 Cancer 1997;70:499-501.

15 Vasen HF, Wijnen JT, Menko FH, Kleibeuker JH, Taal BG, Griffioen G, Nagengast FM, Meijers-Heijboer EH, Bertario L, Varesco L, Bisgaard ML, Mohr J, Fodde R, Khan PM. Cancer risk in families with hereditary nonpolyposis colorectal cancer diagnosed by mutation analysis (published erratum appears in Gastroenterology 1996;111:1402). Gastroenterology 1996;110:1020-7.

16 Boland CR, Thibodeau SN, Hamilton SR, Sidransky D, Eshleman JR, Burt RW, Meltzer SJ, Rodriguez-Bigas MA, Fodde R, Ranzani GN, Srivastava S. A National Cancer Institute Workshop on Microsatellite Instability for cancer detection and familial predisposition: development of international criteria for the determination of microsatellite instability in colorectal cancer. Cancer Res 1998;58:524857.

17 Wijnen JT, Vasen HF, Khan PM, Zwinderman AH, van der Klift H, Mulder A, Tops C, Moller P, Fodde R. Clinical findings with implications for genetic testing in families with clustering of colorectal cancer. $N$ Engl $7 \mathrm{Med}$ 1998;339:511-18.

18 Vasen HF, Mecklin JP, Khan PM, Lynch HT. The International Collaborative Group on Hereditary NonPolyposis Colorectal Cancer (ICG-HNPCC). Dis Colon Rectum 1991;34:424-5.

19 Vasen HF, Watson P, Mecklin JP, Lynch HT. New clinical criteria for hereditary nonpolyposis colorectal cancer (HNPCC, Lynch syndrome) proposed by the International Collaborative group on HNPCC. Gastroenterology 1999; 116:1453-6.

20 Watson P, Vasen HF, Mecklin JP, Jarvinen H, Lynch HT. The risk of endometrial cancer in hereditary nonpolyposis colorectal cancer. Am $\mathcal{F}$ Med 1994;96:516-20.

21 Sijmons RH, Kiemeney LA, Witjes JA, Vasen HF. Urinary tract cancer and hereditary nonpolyposis colorectal cancer: risks and screening options. F Urol 1998;160:466-70.

22 Alani E. The Saccharomyces cerevisiae Msh2 and Msh6 proteins form a complex that specifically binds to duplex oligonucleotides containing mismatched DNA base pairs. Mol Cell Biol 1996;16:5604-15.

23 Edelmann W, Yang K, Umar A, Heyer J, Lau K, Fan K, Liedtke W, Cohen PE, Kane MF, Lipford JR, Yu N, Crouse GF, Pollard JW, Kunkel T, Lipkin M, Kolodner R, Kucherlapati R. Mutation in the mismatch repair gene Msh6 causes cancer susceptibility. Cell 1997;91:467-77.

24 Leppert M, Burt R, Hughes JP, Samowitz W, Nakamura Y, Woodward S, Gardner E, Lalouel JM, White R. Genetic analysis of an inherited predisposition to colon cancer in a family with a variable number of adenomatous polyps. $N$ Engl F Med 1990;322:904-8. 